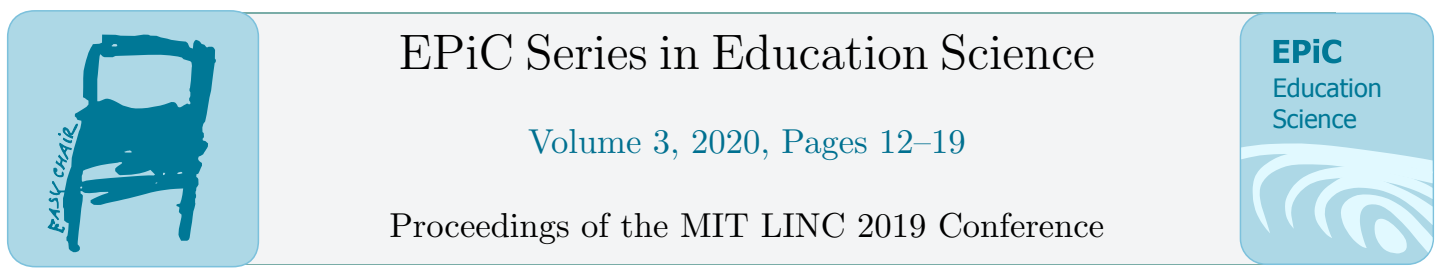

\title{
Meeting the English Language Learning Needs of the Indian Learner
}

\author{
Mydhili Bayyapunedi \\ Product Manager \\ mydhili.b@thehindu.co.in
}

\author{
Pundi Sriram \\ CEO \\ pundi.sriram@thehindu.co.in
}

\author{
Matt Wennersten \\ Visiting Scholar \\ mwenners@gwu.edu
}

\begin{abstract}
In the late 20th century, students learning English in India as a second language had a set of challenges. Classes had mixed ability groups, teaching was carried out in vernacular language and English was taught as a subject and not a skill. Students as well as teachers had few opportunities to learn or practice English. [1] In the 21st century, the challenges from the previous century continued. On the other hand, a new learner has also emerged: the Indian millennial whose access to tech and connectivity has increased along with her expectations from online products and offline services. Millennials of India want collaborative learning experiences and quick feedback, and have low tolerance for boredom. [2]

In this paper we explore two styles of English training for the millennial, online selfpaced and blended (online + face-to-face) where the end-goals of both programs were to help students be an English-confident, job-ready graduate. We present quantitative data and qualitative feedback that shows the difference that the two programs had on the students. From this exploration, we list out a set of design principles for creating an effective English Training program for the Indian Millennial.
\end{abstract}

\section{Introduction}

Frand's [3] list around beliefs of millennials ring especially true for the Indian millennial who has a new-found love for $4 \mathrm{~g}$ broadband speeds. However, characteristics such as "typing is preferred to writing," when extended to Indian youth has become, 'voice is preferred over typing.' [4] This behavior affects how they use English either 
while messaging or searching the internet. Traditional forms of English assessments and instruction are therefore in need of a reformation to meet the millennial learner's needs.

\subsection{State of English among Millennials in India}

Previous research has gone into measuring the effectiveness of English Language courses offered in colleges in India [5][6] and have found them to be failing the students. Engineering students who make up for a considerable portion of graduates entering the Indian job market each year, have commented "written exams must be abolished for English courses. More innovation is required in the methodology for creating enthusiasm" [7]. This lack of communication skills among the students is one of the reasons why a large portion of Indian graduates remain unemployable [8]. Moreover, the inability to speak in a language that was the primary medium of instruction for the majority of their education leaves them doubting their abilities and with a low self-confidence.

\subsection{STEP Test and the STEP Program}

STEP is a standardized online test of English reading, writing, listening and speaking skills, particularly for Indian students and job-seekers. The user's skills are tested using a combination of audio-visual, multiple choice, word order and composition-type questions. STEP levels are aligned to the Common European Framework of Reference.

STEP also offers a learning program that helps learners improve their reading, writing, listening and speaking skills. For colleges and corporates, STEP offers both online-only[app-based and desktop] and blended learning programs. Based on the needs of the students, STEP offers personalized, in-class training that covers the essential LSRW skills. This venture has been backed by The Hindu Group, a leading newspaper and publishing company in India. More information at https://step.thehindu.com

\section{Method}

This paper discusses the results from STEP program conducted at two colleges: Sri Ramakrishna College of Arts \& Science Coimbatore (SNR) and Rajeev Gandhi Memorial College of Engineering \& Technology (RGMCET). We compare their results to a representative control group of students who took a comparable baseline and 
endline test within the gap of a year but had not gone through the STEP Learning program.

\subsection{Student makeup.}

Students from SNR come from a mix of urban and rural households while those at RGMCET, come predominantly from a rural background. Students from both colleges belong to a range of income brackets and are representative of the Indian college-going demography. Both colleges employ English as their medium of instruction.

Our control group of 30 is similar to the two groups above in that they are in a similar age group, employed English as their medium of instruction, and are from an urban background. These students were studying in a Vocational College in India and were randomly grouped to be part of a research program that was to put the students through a baseline assessment followed by a year's training in English, finishing up with an endline assessment. However, due in part to the way the one-year long program was rolled out, the students received minimal STEP instruction, averaging about 6 minutes of STEP training a week per student. Thus, they make for a wellmatched natural control group of students who were assessed but did not receive the benefit of the STEP training.

At SNR, students underwent 40 hours of online training and 20 hours in-person training over a period of 10 and 6 days respectively. The blended program was conducted as a bootcamp over the 16 days and the students were split into 6 batches of around 200 students in each batch. The students answered the STEP baseline test at the start of the programme to give a rough estimate of the current levels of their English proficiency, based on which they were further grouped into 12 classes of 30 students each. A midline progress check was taken at the end of the online training and an endline assessment cum certification test was taken at the end of the in-person training.

At RGMCET, students began with a baseline test to assess their English communication skills at the start of the program. Following this, they started a 40-hour, selfpaced learning programme that culminated with an endline assessment/certification. There was no in-person training that followed the online program.

\section{Results}


This table summarises the average beginning and ending English language levels of the SNR, RGMCET and control students, all measured in STEP levels. 2 STEP levels is roughly equivalent to $1 \mathrm{CEFR}$ level as per the second table below

\begin{tabular}{|l|l|l|l|l|l|}
\hline Group & $\begin{array}{l}\text { \# of stu- } \\
\text { dents }\end{array}$ & Treatment & $\begin{array}{l}\text { Baseline STEP } \\
\text { Level }\end{array}$ & $\begin{array}{l}\text { Endline STEP } \\
\text { Level }\end{array}$ & $\begin{array}{l}\text { Change in } \\
\text { STEP Level }\end{array}$ \\
\hline Control & 37 & None & 5.2 & 5.6 & 0.4 \\
\hline SNR & 1066 & Blended & 5.5 & 6.8 & 1.3 \\
\hline $\begin{array}{l}\text { RGMCE } \\
\text { T }\end{array}$ & 1073 & Online & 6.7 & 8.0 & 1.3 \\
\hline
\end{tabular}

\begin{tabular}{|l|l|l|l|l|l|l|}
\hline CEFR & Level & STEP Level & CEFR & Level & STEP Level \\
\hline C2 & Mastery & $11-12$ & B1 & Intermediate & $5-6$ \\
\hline C1 & Advanced & $9-10$ & A2 & Elementary & $3-4$ \\
\hline B2 & $\begin{array}{l}\text { Upper Inter- } \\
\text { mediate }\end{array}$ & $7-8$ & A1 & Beginner & $1-2$ \\
\hline
\end{tabular}

The control group of students, having completed a year of English-medium academic instruction, improved their English skills by 0.4 STEP levels. The online and blended program participants however, strongly outperformed controls. Absolute improvement varied by starting level and time-spent, with improvement strongly correlated to time-spent. RGMCET Students (Online-only) showed strong motivation and completed an average of 35 hours of the online course. SNR students(Blended) completed an average of 25 hours of the online portion. Students starting at a low skill level saw the most improvement, while those with high levels of skills prior to the course maintained or strengthened those skills. This table summarises by starting skill level plus online effort and the corresponding STEP Level improvement: 


\begin{tabular}{|l|l|l|}
\hline Skill Level / Effort & $\begin{array}{l}\text { SNR } \\
\text { (Blended) }\end{array}$ & $\begin{array}{l}\text { RGMCET } \\
\text { (Online) }\end{array}$ \\
\hline Low skills, low study (Start STEP $<5,<20$ hours) & 1.2 & No data \\
\hline Low skills, high study (Start STEP $<5,>30$ hours) & 2.1 & 2.5 \\
\hline Medium skills, medium study (Start STEP 5-7, 30 hrs) & 1.5 & 1.6 \\
\hline High skills, low study (Start STEP 7+, $<20$ hours) & 1.0 & No data \\
\hline High skills, medium/high study (Start STEP 7+, 30+ hours) & 1.3 & 1.0 \\
\hline
\end{tabular}

\begin{tabular}{|l|r|r|}
\hline Improvement by Category & \% of RGMCET & \% of SNR \\
\hline $\begin{array}{l}\text { Number of Learners with }<1 \text { STEP level improve- } \\
\text { ment: }\end{array}$ & $60 \%$ & $38 \%$ \\
\hline $\begin{array}{l}\text { Number of Learners with }>1 \text { and }<2 \text { STEP Level } \\
\text { improvement: }\end{array}$ & $16 \%$ & $33 \%$ \\
\hline $\begin{array}{l}\text { Number of Learners with }>2 \text { STEP Levels improve- } \\
\text { ment: }\end{array}$ & $24 \%$ & $29 \%$ \\
\hline
\end{tabular}

RGMCET students began the program relatively stronger, with 826 students at CEFR B2 or above, and gains at RGMCET were concentrated amongst the lower initial skill students. SNR students were less diligent in completing the online portion but received a higher overall amount of time-on-task due to the face-to-face training, leading to more uniform gains.

\section{Qualitative Feedback}

In addition to STEP level increases, students from both schools showed significant levels of improvement in speaking and gave positive feedback on the course, as follows: 


\begin{tabular}{|l|l|l|}
\hline Survey & SNR & RGMCET \\
\hline $\begin{array}{l}\text { Overall, how would you rate } \\
\text { the training programme? }\end{array}$ & $\begin{array}{l}3.74 \text { / 4 with 73\% of re- } \\
\text { spondents rating the program } \\
\text { as "4 - Excellent" }\end{array}$ & $\begin{array}{l}\text { 4.02 / 5 with 50\% of } \\
\text { respondents rating the } \\
\text { online training pro- } \\
\text { gramme as "5 - Excel- } \\
\text { lent". }\end{array}$ \\
\hline $\begin{array}{l}\text { Was the training content inter- } \\
\text { esting? Was the training con- } \\
\text { tent useful? }\end{array}$ & $\begin{array}{l}\text { 97\% of respondents found } \\
\text { the training content "Good", } \\
\text { or "Excellent" }\end{array}$ & $\begin{array}{l}\text { 90\% of students found } \\
\text { the training content } \\
\text { "Good", "Very } \\
\text { Good", or "Excellent" }\end{array}$ \\
\hline Sample student comments & $\begin{array}{l}\text { "the trainers encouraged in- } \\
\text { teraction as well as english } \\
\text { speak" } \\
\text { "the trainer makes us to } \\
\text { speak better" } \\
\text { "many interesting classes, } \\
\text { teaching method is very } \\
\text { good" }\end{array}$ & $\begin{array}{l}\text { "This is the excellent } \\
\text { web which I have } \\
\text { never seen, any thing } \\
\text { we can mange by do- } \\
\text { ing step in Eng- } \\
\text { lish.Thanking for } \\
\text { step." } \\
\text { "...in the past I was } \\
\text { very disappointed that } \\
\text { why i cant listen } \\
\text { words when someone } \\
\text { speak English very } \\
\text { fluently but now I am } \\
\text { improved that skill." }\end{array}$ \\
\hline
\end{tabular}

\section{Design Principles}

The experience of the students in the blended and online program indicate the following design principles:

A. Design an easy entry for low-skilled students: Low skilled yet highly motivated students see highest gains: The strongest online gains were concentrated in the most dedicated, weakest skill students, implying that access to high quality learning resources had been a barrier for these highly motivated learners. Providing them with an entry-point that feels do-able helps with stickiness as well as motivation. 
B. Be adaptive for the high-skilled learners: Students who began the course with high skills gained relatively less from the course, with most students ending the program at B2. Online learning serves a bridge to proficiency and not necessarily advanced fluency.

C. Use blended learning where motivation is lower: Online learning affords highlevels of personalization, with students able to start at different levels. For less motivated students, attending a common ability group face-to-face session compensated for reduced online study, leading to similar average outcomes and more even learning gains.

\section{Discussion}

Further research is needed to validate some of our findings in the differences introduced in the control groups and how that may have influenced their outcomes in the Listening, Speaking, Reading and Writing skills. However, from our understanding of the Indian Millennial learners and their learning preferences, we are able to list a few Pedagogical principles that we believe will help the community in general to produce more such programs. We continue to run the STEP program at various colleges in rural and Urban India that help us update our understanding and in turn inform the design principles to develop a course that works for this new learner.

\section{References}

[1] Roy, N. (2017, October). Challenges in Indian Classrooms to Teach English as a Second Language. In Conference proceedings. ICT for language learning (p. 496). libreriauniversitaria. it Edizioni. https://conference.pixel-online.net/ICT4LL/files/ict411/ed0010/FP/3978-

\section{SLA2572-FP-ICT4LL10.pdf}

[2] D'Souza, M. J., \& Rodrigues, P. (2015). Engaging millennial students in an engineering classroom using extreme pedagogy. Indian Journal of Science and Technology, 8(24). http://www.indjst.org/index.php/indjst/article/view/79959/61940

[3] Frand JL. The information-age mindset: Changes in students and implications for higher education. EDUCAUSE Review. 2000; 35(5):15-24

[4] Bellman, E. (2017, August 7th). The End of Typing: The Next Billion Mobile Users Will Rely on Video and Voice. The Wall Street Journal. Link

[5] Pandey, M., \& Pandey, P. (2014). Better English for better employment opportunities. International journal of multidisciplinary approach and studies, 1(4), 93. 
[6] Blom, A., \& Saeki, H. (2011). Employability and skill set of newly graduated engineers in India. Policy research working paper (p. 5640). World Bank, Washington DC 1-33.

[6]Clement, A., \& Murugavel, T. (2015). Professional Development of English Professors in Indian Engineering Colleges: The Need of the Hour. English Language Teaching, 8(5), 132142. https://files.eric.ed.gov/fulltext/EJ1075200.pdf

[8]Aspiring Minds. (2014). National employability report - Engineers. Annual report-2014 (pp. 1-63). 